\title{
INFLUENCE OF DIETARY SUPPLEMENTATION OF VARIOUS SELENIUM SOURCES ON NUTRIENT DIGESTIBILITY, GROWTH PERFORMANCE AND BLOOD METABOLITES IN MALE BUFFALO CALVES
}

\author{
M. M. Farghaly ${ }^{1}$, E. H. Hassan ${ }^{2}$ and Sh. M. Abdel-Raheem ${ }^{3}$ \\ ${ }^{1}$ Department of animal Production, Faculty of Agriculture, Assiut University, Assiut, Egyp. \\ ${ }^{2}$ Department of animal Production, Faculty of Agriculture, Al-Azhar University, Assiut, Egypt. \\ ${ }^{3}$ Department of Animal Nutrition and Clinical Nutrition, Faculty of Veterinary Medicine, Assiut \\ University, Assiut, Egypt.
}

(Received 17/5/2017, accepted 1/7/2017)

\section{SUMMARY}

\begin{abstract}
$\Delta$ n experiment was conducted to compare the effect of organic (selenized yeast) and inorganic (Naselenite) selenium on nutrient digestibility, growth performance and blood parameters of growing buffalo claves. Fifteen Egyptian healthy male buffalo calves were divided randomly into three groups (5 animals each). The treatment groups were as follows: control group (G1) fed basal diet without selenium supplement and treated groups fed $0.22 \mathrm{mg} \mathrm{Se} / \mathrm{kg} \mathrm{DM}$ as either $\mathrm{Na}$-Selenite (G2) or selenized yeast (G3) to the concentrate mixture. All animals were fed $70 \%$ of their requirements as concentrate mixture, while wheat straw given as roughages ad libitum The results indicated that there were significant $(\mathrm{P}<0.05)$ improvements in the digestibility coefficient of organic matter, crude protein, either extract and crude fibre due to dietary supplementation of both Se- yeast and Na-Selenite. No significant differences were observed in growth rate and total dry matter intake of calves between treatments groups. Dietary Se-yeast and Na-selenite supplementation led to significantly $(\mathrm{P}<0.05)$ improved fed conversion ratio for calves as compared with control group (10.86 and 11.09 vs. 11.99). Calves fed Se-yeast or Na-Selenite supplement had increased (P < $0.05)$ concentrations of selenium in whole blood, greater activity $(\mathrm{P}<0.05)$ of blood glutathione peroxidase $(\mathrm{GSH}-\mathrm{Px})$ with lower $(\mathrm{P}<0.05)$ cholesterol and urea concentration than those fed the control diet. In conclusion, dietary supplementation with Se-yeast was more effective than sodium selenite in improving nutrient digestibility, feed conversion efficiency and increasing both Se concentration and GSH-Px activity in the blood of buffalo calves.
\end{abstract}

Key words: Selenium sources; growth performance; nutrient digestibility; buffalo calves

\section{INTRODUCTION}

Selenium (Se) plays important roles in several metabolic process including antioxidant defense systems, thyroid hormone metabolism and immune function (Brown and Arthur 2001). The low selenium level or low bioavailability in soils is reflected in naturally low selenium content of feedstuffs results in animals being deficient in this element (Johnson et al. 2010). The absorption of selenium in ruminants was limited because its mineral compounds are strongly reduced to unavailable forms by rumen bacteria (Pavlata et al., 2002). The factor that reduces the absorption is low rumen $\mathrm{pH}$, especially the high-yielding cows that receive high doses of energy feed. In addition, some elements extremely reduce selenium absorption (e.g. magnesium); however, vitamins $\mathrm{C}$ and $\mathrm{E}$ facilitate its absorption (Kondracki and Bednarek 1996).

The Federal Drug Administration (FDA) in 1987 was amended the dose of Se supplement to ruminant diets from $0.1 \mathrm{ppm}$ at that time to $0.3 \mathrm{ppm}$ at time. In September 2003 the FDA, was modified again to permit the use of selenium yeast (Se-yeast) in diets for dairy and beef animals instead of sodium selenite and selenate.

Selenium supply to ruminant diets in the inorganic or organic form. Sodium selenite is most frequently applied in the feed industry, which are commonly offered in mineral premixes or injected. Selenized yeast $(\mathrm{Se}-\mathrm{Y})$ is the traditional form of supplying organic selenium, this product grown in high 


\section{Farghaly et al.}

selenium medium. Yeast contains selenium mostly as selenomethionine and also has a major amount of selenium in other forms. The dietary inclusion of selenomethionine lead to more retention of Se in ruminants and much longer than Se from inorganic sources. However, the use of Se-yeast in animal feeds is less favorable, because it is relatively expensive.

Numbers of studies on calves were reported the immune mechanism was improved through proper nutrition. Since selenium plays a significant role in immune mechanism and growth. In addition, organic selenium supplementation could be beneficial to protect the pre ruminant calves against infection and to alleviate the weaning stress, thereby enhancing the production performance. Inclusion of $0.3 \mathrm{ppm} \mathrm{Se}$ in the diet of buffalo calves significantly enhanced their immune status (Shinde et al., 2009)

The current study was carried out to compare the effect of organic (Se-yeast) and inorganic (NaSelenite) selenium on nutrient digestibility, growth performance and blood parameters of growing buffalo claves.

\section{MATERIALS AND METHODS}

\section{Animals, rations and management}

The experiment was conducted at the research farm of Faculty of Agriculture, Al-Azhar University, Assiut branch, Egypt. Fifteen healthy male buffalo calves of 13-14 months of age weighing $152.33 \pm$ $20.61 \mathrm{~kg}$ were divided randomly into three groups of (5 animals each). Group 1 was considered as a control and fed a basal diet consisting of roughage and concentrate mixture without any selenium supplementation. Group 2 fed the basal diet supplemented with $0.22 \mathrm{mg} \mathrm{Se} / \mathrm{kg} \mathrm{DM}$ as sodium selenite ( $\mathrm{Na}$-Selenite), while Group 3 received the same basal diet that supplemented with $0.22 \mathrm{mg} \mathrm{Se} / \mathrm{kg} \mathrm{DM}$ as selenized yeast. The basal diet contains $0.05 \mathrm{mg} / \mathrm{kg} \mathrm{DM} \mathrm{Se}$, and the doses of Se were dietary supplemented to the ration. The source of selenized yeast is (Shandong Long live Bio-technology Co., Ltd. China), while the source of sodium selenite is from (Loba Chemie Pvt.Ltd.107, Wode house Roadm, Mumbai 400005, India). The ingredients of concentrate mixture were $10 \%$ corticated cotton seed meal, $10 \%$ soybean meal, $20 \%$ wheat bran, $56 \%$ yellow corn, $1 \%$ vitamin, $2 \%$ limestone, $1 \%$ sodium chloride. The chemical composition of concentrate mixture is clear in table (1).

The animal's requirements for CP and TDN were calculated according to NRC (2001). All calves of three groups were fed $70 \%$ of their requirements as concentrate mixture while wheat straw was given $a d$ libitum. The quantity of concentrate mixture was adjusted every month according to change in body weight. The animals were randomly allotted to experimental diets.

Rations were offered twice a day and the feed orts were weighed daily through the experimental period and actual feed intake was calculated. Feed conversion ratio was calculated and expressed in terms of kg dry matter (DM) per one-kg body weight gain. Diets were mixed daily and fed twice a day. Animals were housed in a well-ventilated animal shed with cemented floor and provided with feed and water individually. Before morning feeding the calves were weighed at the start of experiment and then every month to determine the changes in the body weight (BW). Clean drinking water with no detectable amounts of Se was provided ad libitum twice (at 10 and $15 \mathrm{~h}$ ). Calves were fed their respective treatment diets for a period of 166 days.

Table (1): Chemical composition of concentrate mixture.

\begin{tabular}{ll}
\hline Chemical analysis & $\%$ \\
\hline $\mathrm{DM}$ & 91.42 \\
$\mathrm{OM}$ & 92.53 \\
$\mathrm{CP}$ & 15.47 \\
$\mathrm{TDN}$ & 63 \\
$\mathrm{CF}$ & 15.56 \\
$\mathrm{EE}$ & 2.94 \\
$\mathrm{NFE}$ & 58.56 \\
$\mathrm{Ash}$ & 9.96 \\
$\mathrm{Se} / \mathrm{mg} / \mathrm{kg}$ DM & 0.05 \\
\hline DM, dry matter; OM, organic matter; CP, crude protein; CF, Crude fiber; EE, ether extract; NFE, Nitrogen free extract.
\end{tabular}




\section{Digestibility trials}

Nutrients digestibilities were carried out using chromic oxide as indicator. Each trial lasted 5-days as preliminary period followed by a 7-day as collection period. The total rations contained approximately $0.5 \% \mathrm{Cr} 2 \mathrm{O} 3$ which has been mixed with the concentrate portion. Twice fecal grab were directly taken from the rectum approximately $200 \mathrm{~g}$ of fresh feces during each 24-hr period and composited by animal at the end of the 7-day collection period. Feces were mixed thoroughly and $20 \%$ of it was sampled and dried at $55^{\circ} \mathrm{C}$ in forced air oven. The dried fecal samples from each animal were grounded through $1 \mathrm{~mm}$ mill screen openings and were saved for chemical analysis.

\section{Chemical analysis and digestion coefficients measurements}

The chemical analysis of feeds and faeces were accomplished according to the procedures of Association of Official Analytical Chemists AOAC, (1999) by using duplicate samples. Chromic oxide was analyzed by atomic absorption spectrophotometer by the methods described by Williams et al (1962). The apparent digestion coefficients of nutrients were calculated by expressing the difference between the content of nutrient in both consumed feed and faeces as a percentage of its intake, according to Van Keulen and Young (1977)

\section{Blood sampling}

Blood samples were collected from the jugular vein monthly after the morning feeding. Blood samples were divided in two parts; the first part was taken to measure Se concentration and GSH-Px activity. While, the second part was immediately centrifuged at $3000 \mathrm{rpm}$ for $20 \mathrm{~min}$. and serum was stored at $-20{ }^{\circ} \mathrm{C}$ until analysis. Concentration of serum total protein (TP), albumin (AL), alanine aminotransferase (ALT), aspartate aminotransferase (AST) and cholesterol were determined by spectrophotometer (Unico, USA) using commercial test kits. Serum globulin (GL g/dl) was obtained as the difference between the total protein and albumin concentration. The concentration of Se in whole blood and diets was determined by atomic absorption spectrometry (Norheim and Haugen, 1986). Samples were prepared by oxidative digestion in a mixed solution with concentrated nitric and perchloric acids, using an automated system. The activity of GSH-Px was determined in whole blood of calves with commercial test kits. Method for determination of GSH-Px is based on catalytic oxidation of glutathione by hydroxide peroxide, and spectrophotometer (UV/VIS JENWAY 6305) used for reading as described by Sankari (1985).

\section{Statistical analysis}

Statistical analysis was done according to general linear model (G.L.M) of S.A.S program (2001), version 8.2. Differences between groups in nutrient digestibility coefficient, blood metabolites and growth performance data were evaluated by one-way ANOVA. Duncan Multiple Range Test (Steel and Torrie, 1980) was used to test the effect of treatments. The data were presented as mean \pm S.E.M. Level of significance was set at $\mathrm{P}<0.05$. Statistical model as follow:

$$
Y_{i j}=\mu+T_{i}+E_{i j}
$$

Where: $\mathrm{Y}_{\mathrm{ij}}=$ The observation $\mathrm{ij}, \mu=$ The overall mean, $\mathrm{T}_{\mathrm{i}}=$ The effect due to treatment $\mathrm{i}$, $\mathrm{E}_{\mathrm{ij}}=$ The experimental error.

\section{RESULTS AND DISCUSSION}

\section{Nutrients digestibility coefficient}

The average values of nutrients digestibility are presented in table (2). The organic matter (OM), crude protein $(\mathrm{CP})$ and either extract $(\mathrm{EE})$ digestibility coefficient were significantly $(\mathrm{P}<0.05)$ improved for calves fed supplemented Se-yeast (G2) and Na-Selenite (G3) than control group (G1). Also, crude fibre $(\mathrm{CF})$ digestibility coefficient was improved $(\mathrm{P}<0.05)$ in Se-yeast group more than Na-Selenite and control groups. The increased nutrient digestibility in Se-yeast treatments suggests positive impacts of Seyeast on rumen microorganisms rather than the host as previously illustrated by Alimohamady et al. (2013). In addition, this finding was in agreement with those found by Saleem (2016) he revealed that digestibility of DM, OM, CP, neutral detergent fiber (NDF) and acid detergent fiber (ADF) improved for lambs fed on Se-yeast supplementation as compared with control lambs. Also, Shi et al (2011) stated an 


\section{Farghaly et al.}

improvement in total digestibility of dry matter, crude protein, ether extract and NDF due to increase in Se level from 0.15 to $0.45 \mathrm{mg} \mathrm{Se} / \mathrm{kg} \mathrm{DM}$ in male goats.

Table (2): Effects of dietary Se source on nutrient apparent digestibility coefficient and feeding value of rations.

\begin{tabular}{|c|c|c|c|c|}
\hline \multirow{2}{*}{ Item } & \multicolumn{3}{|c|}{ Treatment } & \multirow{2}{*}{ P-value } \\
\hline & Control & Se-yeast & Na-Selenite & \\
\hline \multicolumn{5}{|l|}{ Apparent digestibility coefficient } \\
\hline $\mathrm{DM}$ & $60.50^{\mathrm{b}} \pm 0.79$ & $67.90^{\mathrm{a}} \pm 1.16$ & $65.26^{\mathrm{a}} \pm 0.33$ & 0.001 \\
\hline $\mathrm{OM}$ & $62.35^{\mathrm{b}} \pm 0.85$ & $65.86^{\mathrm{a}} \pm 0.54$ & $65.53^{\mathrm{a}} \pm 0.87$ & 0.033 \\
\hline $\mathrm{CP}$ & $70.26^{\mathrm{b}} \pm 1.06$ & $77.14^{\mathrm{a}} \pm 0.30$ & $75.30^{\mathrm{a}} \pm 0.17$ & 0.001 \\
\hline $\mathrm{CF}$ & $51.87^{\mathrm{b}} \pm 1.02$ & $57.72^{\mathrm{a}} \pm 1.65$ & $52.52^{\mathrm{b}} \pm 1.29$ & 0.041 \\
\hline $\mathrm{EE}$ & $64.96^{\mathrm{b}} \pm 0.24$ & $74.06^{\mathrm{a}} \pm 1.29$ & $71.97^{\mathrm{a}} \pm 1.28$ & 0.002 \\
\hline NFE & $65.34 \pm 0.57$ & $64.13 \pm 2.12$ & $66.79 \pm 0.75$ & 0.426 \\
\hline \multicolumn{5}{|l|}{ Feeding Value } \\
\hline TDN & $61.50 \pm 1.56$ & $63.37 \pm 1.56$ & $63.70 \pm 0.62$ & 0.307 \\
\hline SE & $51.58 \pm 0.33$ & $53.35 \pm 1.55$ & $53.70 \pm 0.62$ & 0.331 \\
\hline DCP & $7.05 \pm 0.07$ & $7.18 \pm 0.21$ & $7.28 \pm 0.09$ & 0.528 \\
\hline
\end{tabular}

The feeding value in terms of total digestible nutrients (TDN), starch equivalent (SE) and digestible crude protein (DCP) was not affected with supplemented Se-yeast and Na-Selenite to claves diets. Nicholson et al. (1991) found no effect with Se supplementation to all ration of lambs and buffalo calves on nutritive value of ration (TDN and DCP). However, Taheri et al. (2016) reported that organic selenium seems to be a better choice, considering the nitrogen and energy available for metabolism and production in native goats.

\section{Growth performance}

Results presented in table (3) showed that the differences among all groups in body weight gain and daily weight gain were not significant.These findings are in line with those obtained by Mateo et al. (2007). Vinu et al (2012) found that supplemented Se-yeast at rate $0.3 \mathrm{ppm}$ to calves diets did not reveal any significant difference on daily body weight gain as compared with control. Similarly, Lawler et al. (2004) showed that the growth performances of bulls in growing and finishing cattle were not affected by supplement different sources of Se. Also, the lack effect of Se on growth rate of finishing lambs fed 0.3 $\mathrm{mg}$ Se-yeast/kg DM was conducted by Dominguez-Vara et al. (2009).

Table (3): Growth Performance of buffalo calves fed different sources of selenium.

\begin{tabular}{lcccc}
\hline \multirow{2}{*}{ Item } & \multicolumn{3}{c}{ Treatment } & \multirow{2}{*}{ P- Value } \\
\cline { 2 - 4 } & Control & Se-yeast & Na-Selenite & \\
\hline Initial weight $(\mathrm{kg})$ & $152.50 \pm 24.48$ & $152.00 \pm 15.21$ & $152.50 \pm 22.13$ & 0.999 \\
Final weight (kg) & $265.75 \pm 26.68$ & $275.00 \pm 25.42$ & $273.75 \pm 25.89$ & 0.963 \\
BW gain (kg) & $113.25 \pm 3.01$ & $123.00 \pm 12.73$ & $121.25 \pm 5.01$ & 0.695 \\
Daily gain (kg) & $0.682 \pm 0.031$ & $0.741 \pm 0.076$ & $0.730 \pm 0.03$ & 0.695 \\
Feed Intake (FI, kg/day) & & & & 0.808 \\
DMI of concentrate & $5.22 \pm 0.086$ & $5.14 \pm 0.079$ & $5.18 \pm 0.083$ & 0.003 \\
DMI of wheat straw & $2.96^{\mathrm{a}} \pm 0.016$ & $2.91^{\mathrm{b}} \pm 0.010$ & $2.91^{\mathrm{b}} \pm 0.010$ & 0.541 \\
Total DM intake & $8.18 \pm 0.089$ & $8.05 \pm 0.082$ & $8.09 \pm 0.083$ & 0.001 \\
Feed conversion ratio kg DM & $11.99^{\mathrm{a}} \pm 0.13$ & $10.86^{\mathrm{b}} \pm 0.11$ & $11.09^{\mathrm{b}} \pm 0.11$ & 0.001 \\
intake/kg gain) & & & & \\
\hline
\end{tabular}

*BW, Body weight; DMI, Dry matter intake

${ }^{a, b}:$ Means with different superscripts within a row are significantly different at $(P<0.05)$ for treatment effect. 
Also, the results indicated that there were no significant differences in total dry matter intakes (DM) among all treatments groups (Table3). On the other hand, buffalos fed rations supplement with Se-yeast and Na-Selenite were significantly $(\mathrm{P}<0.05)$ higher for dray matter intake of wheat straw than fed control ration. The disappearance of the effect ether organic or nonorganic Se on feed intake and body weight gain of calves buffalos may be due to that Se requirements of the animals involved in our trial were so far covered by Se amount as analyzed in the basal diet (Alimohamady et al., 2013). However, these results agreement with findings of Vinu et al. (2012) reported that the total DM intake of calves not significant affected with supplemented $0.3 \mathrm{ppm}$ organic selenium as compared with control one. Similarly, Juniper et al. (2008) observed no effect of different dietary levels of selenium ( 0.2 to $6.74 \mathrm{ppm})$ as selenium yeast on the dry matter intake on ruminant.

Data in Table (3) illustrated that supplement Se-yeast and Na-selenite to rations was improved significantly $(\mathrm{P}<0.05)$ feed conversion ratio of growing buffalos. This may be due to positive effect of selenium source on nutrient digestibility or due to the tendency increase on daily body weight gain of supplements groups as it is clear in (Table3). The improvement of feed conversion ratio was previously observed with Se sources supplemented to lambs by Saleem (2016) and Grace and Knowles (2002). In contrast, Juniper et al. (2008) observed no treatment effect on the feed efficiency in calves and lambs when supplemented with 5.86 and 6.63 ppm of selenium as selenium yeast.Also, Richards et al (2011) reported no significant effect in the feed gain ratio on dietary supplementation of $0.34 \mathrm{ppm}$ of selenium yeast in beef cattle.

\section{Blood metabolites}

The data of serum parameters are summarized in Table (4). Supplemented Se-yeast and Na-Selenite to claves rations not effected on total protein, but decreased significantly $(\mathrm{P}<0.05)$ albumin and albumin $\backslash$ globulin ratio as compared with control group. However, the value of globulin was significantly $(\mathrm{P}<0.05)$ higher in supplement groups than control one. The low values of plasma albumin in supplement groups lead to increase the level of plasma globulin in these groups as compared with control group. The higher value of globulin found with supplement Se groups may be due to the effect of Se supplementation, which increase significantly $(\mathrm{p}<0.05)$ total serum globulins, specificity $\gamma$-globulins as comparing with control (Hamam and abou zeina, 2007). Similarly, Shinde et al. (2009) found that supplementation of selenium and Vitamin $\mathrm{E}$ in the diet of buffalo calves had no effect on serum total protein.

Table (4): Effects of dietary Se source on some serum and whole blood metabolites

\begin{tabular}{lllll}
\hline \multirow{2}{*}{ Item } & \multicolumn{3}{c}{ Treatment } & \multirow{2}{*}{ P-Value } \\
\cline { 2 - 4 } & \multicolumn{1}{c}{ Control } & \multicolumn{1}{c}{ Se yeast } & Na-selenite & \\
\hline Total protein $(\mathrm{g} / \mathrm{dl})$ & $6.73 \pm 0.08$ & $7.03 \pm 0.11$ & $6.84 \pm 0.11$ & 0.126 \\
Albumin $(\mathrm{g} / \mathrm{dl})$ & $4.03^{\mathrm{a}} \pm 0.17$ & $3.57^{\mathrm{b}} \pm 0.04$ & $3.36^{\mathrm{b}} \pm 0.11$ & 0.003 \\
Globulin $(\mathrm{g} / \mathrm{dl})$ & $2.71^{\mathrm{b}} \pm 0.24$ & $3.46^{\mathrm{a}} \pm 0.11$ & $3.48^{\mathrm{a}} \pm 0.15$ & 0.007 \\
al/glo ratio & $1.64^{\mathrm{a}} \pm 0.22$ & $1.04^{\mathrm{b}} \pm 0.04$ & $0.99^{\mathrm{b}} \pm 0.07$ & 0.004 \\
$\mathrm{ALT}(\mathrm{U} / \mathrm{l})$ & $25.33^{\mathrm{a}} \pm 2.41$ & $16.77^{\mathrm{b}} \pm 1.06$ & $20.89^{\mathrm{ab}} \pm 1.41$ & 0.007 \\
$\mathrm{AST}(\mathrm{U} / \mathrm{l})$ & $20.33 \pm 1.91$ & $23.22 \pm 1.96$ & $23.89 \pm 1.60$ & 0.359 \\
Cholesterol mg/dl & $204.21^{\mathrm{a}} \pm 7.38$ & $174.01^{\mathrm{b}} \pm 2.32$ & $182.86^{\mathrm{b}} \pm 4.43$ & 0.001 \\
Urea $(\mathrm{mg} / \mathrm{dl})$ & $37.19^{\mathrm{a}} \pm 2.89$ & $23.23^{\mathrm{b}} \pm 0.75$ & $28.78^{\mathrm{b}} \pm 1.46$ & 0.001 \\
Se $(\mu \mathrm{gg} / \mathrm{l})$ & $76.04^{\mathrm{c}} \pm 1.98$ & $138.31^{\mathrm{a}} \pm 2.94$ & $120.18^{\mathrm{b}} \pm 2.60$ & 0.001 \\
GSH-Px $(\mathrm{U} / \mathrm{l})$ & $336.14^{\mathrm{c}} \pm 4.75$ & $606.16^{\mathrm{a}} \pm 6.60$ & $482.98^{\mathrm{b}} \pm 8.28$ & 0.001 \\
\hline a, b,c $:$ Means of the same row in each item with different superscripts are & significantly & different $(P<0.05)$ for
\end{tabular}

The value of ALT in Table 4 was significantly $(\mathrm{P}<0.05)$ decreased for claves group fed supplement to organic Se as compared with control group. However, the values of AST were not apparently affected by Se supplementation. Alimohamady et al. (2013) found that selenium source had no significant effects on serum alkaline phosphatase (ALP), creatine phosphokinase (CPK), and aspartate aminotransferase (AST) activity. Also, Pond et al. (1995) noticed that dietary supplementation with either inorganic or organic Se to the basal diet of goats did not make any differences in serum AST and ALT.

The total cholesterol and blood urea concentration were significantly $(\mathrm{P}<0.05)$ decreased with supplement Se-yeast and Na-selenite as compared with control. This results agreement with those reported previously by Slavik et al. (2008) 


\section{Farghaly et al.}

The results indicate that the supplement Se either inorganic or organic source were significantly $(\mathrm{P}<$ 0.05 ) increase the value of Se in whole- blood as compared with control group (Table 4). Also, the calves received Se-yeast was significantly $(\mathrm{P}<0.05)$ higher of Se concentration on whole-blood than that received Na-selenite. The increase in the mean blood Se concentration of calves received Se-yeast agrees with found by Qin et al. (2007) who found that organically bound Se can readily improve an animal's Se status and is superior to inorganic Se. Saleem (2016) indicated that lambs received Se in inorganic and organic source was significantly higher in blood Se concentrations than control groups. Weiss (2003) found that the concentration of Se in blood was increased at a rate $18 \%$ in cows received Se yeast than those received the same amount of sodium selenite. On other side, Esterhuyse (2012) stated that inorganic Se can contribute in improving Se status of animals.

Also, the results showed that supplement Se-yeast and $\mathrm{Na}$-Selenite to buffaloes calves ration significantly $(\mathrm{P}<0.05)$ increased whole blood GSH-Px as compared with control group (Table 4). The highest values of GSH-Px concentrations were recorded for Se-yeast group, followed by Na-selenite group, while the lowest value was found in the control group. Our results prove the positive correlation between blood Se concentration and blood GSH-Px activity. Correlation between Se concentration and GSH-Px activity was observed also by other studies Pavlata et al. (2001) in cattle, Pavlata et al. (2011) in goats, Rock et al. (2001) in lambs, Panev et al. (2013) in sheep. Similarly, Faixova et al (2007) found that lambs fed additional Se-enriched yeast had high level of Se in plasma, bigger activity of blood glutathione peroxidase $(P<0.001)$ and lower serum activity of creatine kinase.

\section{CONCLUSION}

From the present study, it can be concluded that selenium supplementation in form of organic and inorganic source improved nutrients digestibility coefficients and fed conversion ratio of buffalo calves, but Se-yeast was more effective than sodium. Both Se sources increased Se concentration and GSH-Px activity in the blood of buffalo calves.

\section{REFERENCES:}

Alimohamady, R., Aliarabi, H., Bahari, A. and Dezfoulian, A. H. (2013). Influence of different amounts and sources of Selenium supplementation on performance, some blood parameters, and nutrient digestibility in lambs. Biological trace element research, 154: 45-54.

AOAC (1999). Association of Official Analytical Chemists. Official Methods of Analysis, 16th ed.: AOAC. AOAC, Gaithersburg, MD, USA.

Brown, K.M. and Arthur, J.R. (2001). Selenium, selenoproteins and human health: a review. Public Health Nutrition, 4(2B): 593-599.

Dominguez-Vara, I.A., Gonzalez-Munoz, S.S., Pinos-Rodríguez, J.M., Bórquez-Gastelum, J.L., BarcenaGama, R., Mendoza-Martínez, G., Zapata, L.E. and Landois-Palencia, L.L. (2009). Effects of feeding selenium-yeast and chromium-yeast to finishing lambs on growth, carcass characteristics, and blood hormones and metabolites. Animal Feed Science \& Technology, 152: 42-49.

Esterhuyse, J.J. (2012). The effects of different Selenium sources on the meat quality and bioavailability of Selenium in lamb. Doctoral dissertation, Stellenbosch: Stellenbosch University.

Faixova, Z., Faix, S., Leng, L., Vaczi, P., Makova, Z. and Szaboova, R. (2007). Hematological, Blood and Rumen Chemistry Changes in Lambs Following Supplementation with Se-yeast. Acta Vet. Brno, 76: 3-8.

Grace, N.D. and Knowles, S.O. (2002). A reference curve using blood Selenium concentration to diagnose Selenium deficiency and predict growth responses in lambs. New Zealand veterinary journal, 50: 163-165.

Hamam, A.M. and Hala Abou-Zeina, A.A. (2007) Effect of Vitamin E and selenium supplements on the antioxidant markers and immune status in sheep. J. Biol. Sci., 7: 870-878.

Johnson, C.C., Fordyce F.M. and Rayman, M.P. (2010). Factors controlling the distribution of selenium in the environment and their impact on health and nutrition. Proceedings of the Nutrition Society, 69: 119-132. 
Juniper, D.T., Phipps, R.H., Givens, D.I., Jones, A.K., Green, C. and Bertin, G. (2008) Tolerance of ruminant animals to high dose in-feed administration of a selenium-enriched yeast. J Anim Sci., 86: 197-204.

Kondracki, M. and Bednarek, D. (1996). Meaning of chosen mineral elements in the resistance of animals. Zycie Wet, 3, 85-88.

Lawler, T.L., Taylor, J.B., Finley, J.W. and Caton, J.S. (2004). Effect of supranutritional and organically bound selenium on performance, carcass characteristics and selenium distribution in finishing beef steers. J Anim Sci., 82: 1488-1493.

Mateo, R.D., Spallholz, J.E., Elder, R., Yoon, I. and Kim, S.W. (2007). Efficacy of dietary selenium sources on growth and carcass characteristics of growing-finishing pigs fed diets containing high endogenous selenium. J. Anim. Sci., 85: 1177-1183.

Nicholson, J. W. G., R. E. McQueen, and R. S. Bush. (1991). Response of growing cattle to supplementation with organically bound or inorganic sources of Selenium or yeast cultures. Canadian journal of animal science, 71, 803-811.

Norheim G and Haugen A. (1986). Precise determination of Selenium in tissues using automated wet digestion and an automated hydride generator - atomic absorption spectroscopy system. Acta Pharmacol. Toxicol., 59: 610-612.

NRC (2001). National Research Council. Nutrient Requirement of Dairy Cattle, $7^{\text {th }}$ ed., National Academy of Sciences, Washington D.C.

Panev, A., Hauptmanová, K., Pavlata, L., Pechová, A., Filípek, J. and Dvořák, R. (2013). Effect of supplementation of various selenium forms and doses on selected parameters of ruminal fluid and blood in sheep. Czech J. Anim. Sci., 58 (1): 37-46.

Pavlata L., Pechová A., Bečvář O. and Illek J. (2001). Selenium status in cattle at slaughter: analyses of blood, skeletal muscle, and liver. Acta Veterinaria Brno, 70, 277-284

Pavlata, L., Lilek, J., Pechowa, A. and Matejicek, M. (2002). Selenium status of cattle in the Czech Republic. Acta Vet Brno, 71: 3-8.

Pavlata L., Chomat M., Pechova A., Misurova L. and Dvorak R. (2011). Impact of long-term supplementation of zinc and selenium on their content in blood and hair in goats. Veterinarni Medicina, 56, 63-74.

Pond, W.G., Church, D.C. and Pond, K.R. (1995). Inorganic mineral elements. In: Basic Animal Nutrition and Feeding (4th ed.). John Wiley \& Sons. New York. pp. 167-220.

Qin, S., Gao, J. and Huang K. (2007). Effects of different Selenium sources on tissue Selenium concentrations, blood GSH-Px activities and plasma interleukin levels in finishing lambs. Biological trace element research, 116: 91-102.

Richards, C.J., Blalock, H.M., Jacques, K.A. and Loveday, H.D. (2011). Efficiency of feeding selenium enriched yeast to finishing beef cattle. Proff. Anim. Scient., 27: 1-8.

Rock M.J., Kincaid R.L., Carstens G.E. (2001). Effects of prenatal source and level of dietary selenium on passive immunity and thermometabolism of newborn lambs. Small Ruminant Research, 40, 129138.

Saleem, A.S. (2016). Effect Of different selenium sources on performance of Sohagi Lambs. M.sc., Fac. of Agric., Sohag Univ., Egypt.

SAS (2001). Stat view for Windows, Version 8.2.SAS Institute, Cary, NC, USA.

Sankari, S. (1985). Plasma glutathione peroxidase and tissue selenium response to selenium supplementation in swine. Acta Veternary. Scand. Suppl. 81, 1-20.

Shi L., Xun W., Yue W., Zhang C., Ren Y., Shi L. and Lei F. (2011). Effect of sodium selenite, Se-yeast and nano-elemental Selenium on growth performance, Se concentration and antioxidant status in growing male goats. Small Ruminant Research, 96: 49-52.

Shinde, P.L., Dass, R.S. and Garg, A.K. (2009). Effect of Vitamin E and selenium supplementation on haematology, blood chemistry and thyroid hormones in male buffalo (Bubalus bubalis) calves. J. Anim. Feed Sci., 18: 241-256.

Slavik, P., Josef, I., Michal B, Jaroslava H, Radko, R. and Frantisek, J. (2008). Influence of organic versus inorganic dietary selenium supplementation on the concentration of selenium in colostrum, milk and blood of beef cows. Acta Veterinaria Scandinavica, 50: 43.

Steel, R.G.D. and Torrie, J.H. (1980). Duncan's new multiple range tests. Principles and procedures of statistics, pp:187-188.

Taheri, Z., Karimi, S., Mehrban, H. and Moharrery, H. (2016). Supplementation of different selenium sources during early lactation of native goats and their effects on nutrient digestibility, nitrogen and energy status. Journal of Applied Animal Research, (2016). DOI: 10.1080/09712119.2016.1259625.

Van Keulen, J.V. and B.A. Young (1977). Evaluation of acid insoluble ash as a natural marker in ruminant digestibility studies. J. Animal. Sci. 44:282. 


\section{Farghaly et al.}

Vinu, M.N., Gangadevi, P., Mercy, A.D., Anil, K.S. and Shyama. K. (2012). Effect of dietary supplementation of organic selenium on growth performance and nutrient utilization in cross-bred calves. J. Vet. Anim. Sci., 43: 36-40

Weiss, W.P. (2003). Selenium nutrition of dairy cows: comparing responses to organic and inorganic selenium forms. In Proceeding of the 19th Alltech Annual Symposium utrition, Biotechnology Feed Food: 20-23; Lexington. Nottingham University Press, Nottingham, UK, :333-373.

Williams, C.H., David, D.J. and Iismaa O. (1962). The determination of chromic oxide in fecal samples by atomic absorption spectroscopy. J. Agric. Sci., 59: 381-385.

\section{تاثير اضافه مصادر مختلفة من السلينوم على هضم المكونات الغذائيه ، اداء النمو وخصائص الدم فى ذكور عجول الجاموس دوسافر}

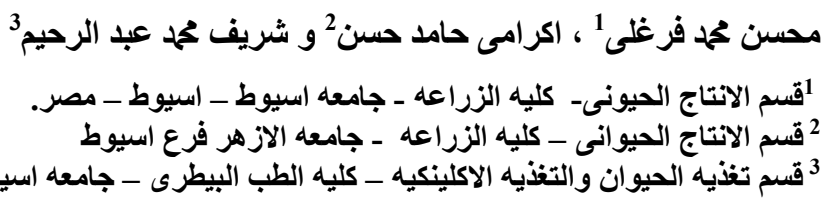

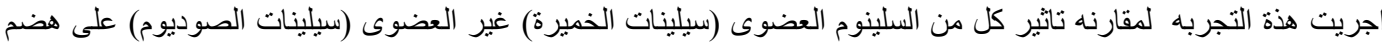

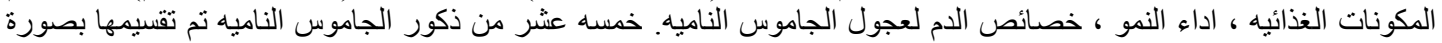

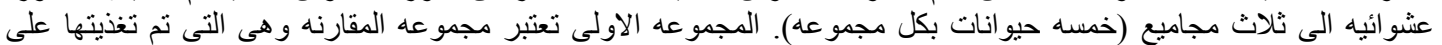

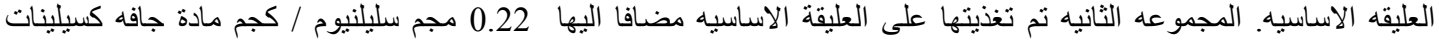

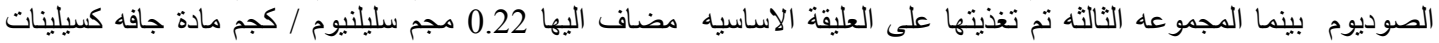

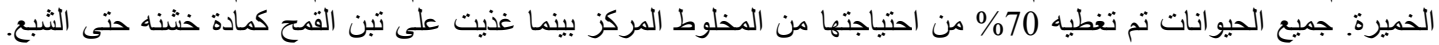

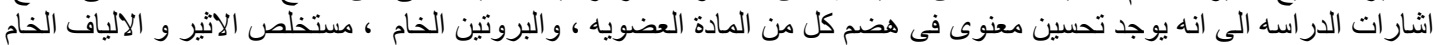

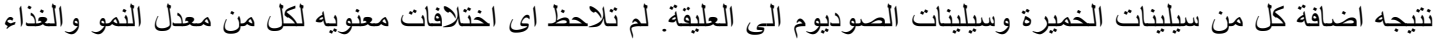

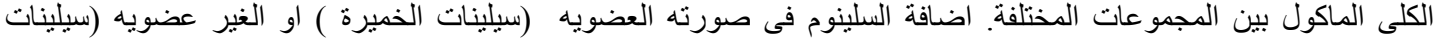

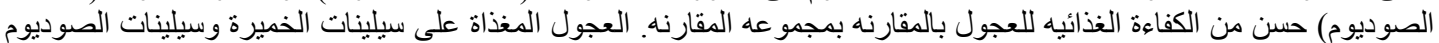

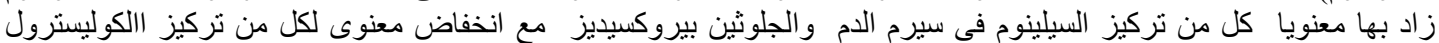

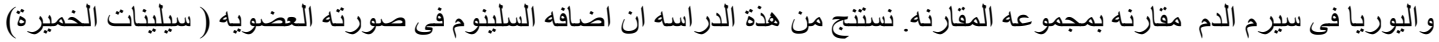
كان اكثر تاثير ا من سيلينات الصوديوم مما ادى الى تلى تحسين هضم المكونات الغذائيه والكفاءة الغذائيه وزيادة تركيز السلينوم فى سيرم

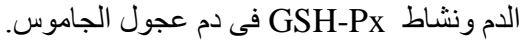

